Plant Morphology 11(1): 2- 13. 1999.

総説

\title{
高等植物胚における茎頂分裂組織形成の制御機構
}

\author{
相田光宏
}

\author{
奈良先端科学技術大学院大学バイオサイエンス研究科 \\ （テ630-0101＼cjkstart奈良県生駒市高山町8916-5）
}

\section{Shoot Apical Meristem Formation during Higher Plant Embryogenesis Mitsuhiro Aida}

\author{
Graduate School of Biological Sciences, Nara Institute of Science and Technology \\ 8916-5 Takayama, Ikoma, Nara 630-0101, Japan
}

\begin{abstract}
要旨: 高等植物のシュートの発生は、頂端部に存在する未分化な細胞集団である茎頂分裂組織に大 きく依存する。胚発生における茎頂分裂組織の形成は、その後の地上部の器官形成を継続しておこ なっていくために重要なステップである。近年のモデル植物を用いた分子遺伝学的解析から、茎頂 分裂組織形成に関わる遺伝子が多く同定され、それらの間の相互関係もわかりつつある。これらの 解析から、茎頂分裂組織の形成を制御する分子プログラムは形態的な特徵が明らかになるよりかな り早くはじまり、いくつかのステップを経て進行していく過程であることがわかってきた。
\end{abstract}

Summary: Shoot development of higher plants is largely dependent on the shoot apical meristem, a small group of undifferentiated cells at the tip. Establishment of the meristem during embryogenesis is an important step for postembryonic shoot organ formation. Recent molecular genetic studies have led to the identification of numerous genes which are important for this step. These analyses have demonstrated that the molecular program responsible for shoot meristem formation starts long before morphological features of the meristem become evident, and progresses through several steps.

Key Words: shoot apical meristem, embryogenesis, higher plants, molecular genetics

1.はじめに

高等植物の発生は動物と異なり、一生を通じて新しい器官を作り続けるという点で大きな特徵を 持つ（Steeves and Sussex 1989; Wolpert et al. 1998）。植物体の頂端部に存在する茎頂分裂組織 は、地上部における器官形成の中心として働く（Sussex 1989）。茎頂分裂組織の細胞は、自分自 身を維持するために未分化な状態を保持しつつ、新たな器官・組織を構成する細胞を供給し続ける という、幹細胞としての性質を持つ。葉・茎・花など地上部の器官はほとんどが茎頂分裂組織から 
形成される。茎頂分裂組織がどのように形成され、どのように機能するかを理解することは、植物 の発生を考える上で欠くことのできない重要なテーマである。

被子植物の茎頂分裂組織は層構造を持っており、1 数層の細胞層からなる外衣（tunica）と内 側の内体（corpus）に分けることが出来る。この構造は茎頂分裂組織における細胞分裂のパターン を反映している。外衣の細胞は原則的に垂層分裂のみを行うため層構造が保たれる。一方、内体の 細胞の分裂方向は様々であり、はっきりした層をなさない。外衣・内体とは別に、茎頂分裂組織を 中央帯 (central zone: CZ)、周辺分裂組織 (peripheral meristem: PM)、髄状分裂組織（rib meristem: RM）の三つの区域に分けることもできる。各区域は実際の分裂組織の機能と対応すると 考えられている。CZの細胞は未分化な状態を維持しながら周囲のPM、RMへ細胞を供給する。PM は未分化な細胞が側方器官の細胞へと分化していく領域で、RMは茎の内部組織が分化する領域であ る。

茎頂分裂組織の形成は、それがいつどこで起こるかによって大きく三つに分けられる。一つ目は 胚発生過程における一次分裂組織（primary meristem）の形成である。これは胚の基本体制の確立 にともなって起こり、胚発生後に器官形成を継続していく上で必須の過程である。二つ目は葉腋に おける腋生分裂組織（axillary meristem）の形成である。植物体は種によって、また環境要因に よってさまざまな分枝形態をとりうるが、その要因の一つは腋生分裂組織の働きである。最後に植 物体は葉・茎・根などさまざまな成熟器官や組織培養したカルスから不定芽を生ずる。これにとも なって不定芽の分裂組織（adventitious meristem）が形成される。

近年、シロイヌナズナなどのモデル植物を用いた分子遺伝学的解析により、茎頂分裂組織の形成 や維持に重要な働きを持つと考えられる遺伝子が次々と同定され、これらの過程を制御する遺伝的 メカニズムが次第に明らかにされつつある。本稿では高等植物の胚発生過程における一次分裂組織 の形成に主に焦点をあて、この過程に関わる遺伝子とそれらの遺伝子間の相互作用について、最新 の知見を紹介したい。

\section{2. 胚発生における菱頂分裂組織の形成過程}

双子葉植物の胚発生では、茎頂分裂組織は 2 つの子葉の間に形成される。茎頂分裂組織の形態的 な特徵が胚発生のどの時期に確立されるかは植物種によって異なり、子葉原基が形成される前にす でに明らかになっているものもあれば、数枚の本葉原基を形成するまではっきりとした構造が観察 されないものもある（Kaplan and Cooke 1997; Lyndon 1998）。

図 1 にシロイヌナズナの胚発生過程を示す。接合子はまず規則的な細胞分裂を経て、球状の胚本体 (球状胚) と胚柄を形成する。この球状胚の頂端中央部から茎頂分裂組織が、両側 2 力所から子葉 ができる。まず球状胚の上部 2 力所の細胞が活発に分裂を始め、子葉原基が盛り上がる（心臓 胚）。一方、子葉原基の間にあって後の茎頂分裂組織になっていく部分では、しばらくの間盛り上 がりが押さえられている。その後子葉屈曲期になると、この領域の細胞が外衣・内体に特徵的な分 裂パターンをとり始め、子葉と子葉の間を押し分けるように広がってドーム状の茎頂分裂組織を形 成する（Barton and Poethig 1993）。

このように、シロイヌナズナの場合、茎頂分裂組織が組織学的に明確になる時期は胚発生の比較 的後期であり、その他の組織系である子葉・胚軸・根端分裂組織の形成よりも遅い。しかし近年の 解析から、茎頂分裂組織に関与する遺伝子の発現は茎頂分裂組織が形態的に明らかになるよりも ずっと早い時期に始まることがわかってきた。つまり、茎頂分裂組織形成を制御する分子プログラ ムは胚発生のかなり初期の段階から始まっているらしい。 


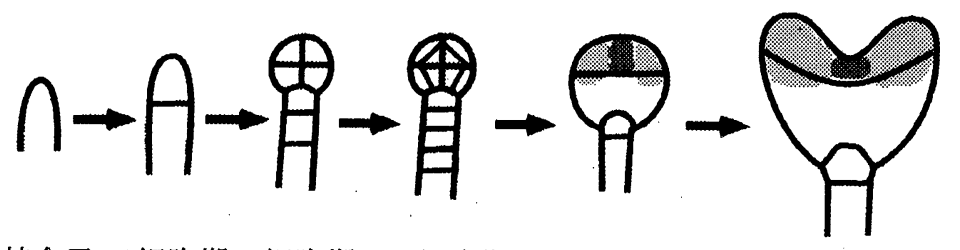

図 1 シロイヌナズナの胚発生. 茎頂分裂組織を形成する領域を濃 い影, 子葉を形成する領域を薄い 影で表す。

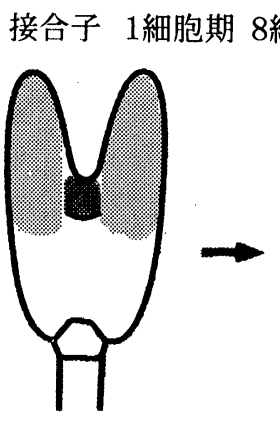

魚雷胚期
球状胚期

心臟胚期

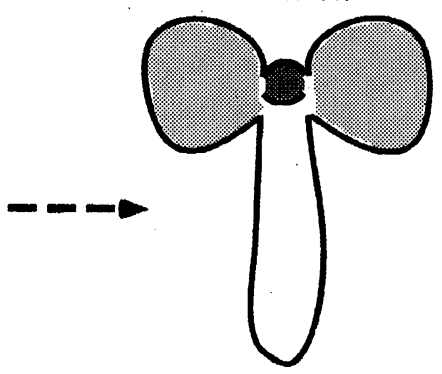

芽生え

\section{3. 胚頂端部の運命の決定}

茎頂分裂組織は胚のもっとも頂端部に形成される。茎頂分裂組織が形成されるためには、胚の中 で頂端一基部の極性が形成され、頂端部の運命が決定されることが前提となる。シロイヌナズナの 劣性突然変異体topless（tpl） は頂端部の運命の決定に異常を引き起こす（Evans and Barton 1997; Long et al. 1999）。この変異体は温度感受性で、制限温度下で形成された胚では頂端側の構造であ る茎頂分裂組織・子葉・胚軸が全て欠失し、かわりに第二の根が形成される。その結果、頂端一基 部軸の両端に根端を持つ鏡像対称な芽生えになる。野生型の胚では茎頂分裂組織に特異的な遺伝子 であるSHOOT MERISTEMLESS (STM) やUNUSUAL FLORAL ORGANS (UFO) が頂端部で 発現するが、tpl変異体ではこれらの遺伝子の発現がみられず、かわりに根端分裂組織に特異的なマ 一カー遺伝子の発現が頂端部でもみられた。以上のことから、TPL遺伝子は胚の頂端部の運命の決 定に重要な役割を持つことが示唆される。

\section{4. 胚頂端部の領域化}

シロイヌナズナの胚は細胞分裂のパターンがかなり規則的なので、どの領域が将来の子葉および 茎頂分裂組織になるかは、球状胚の時期ですでに予測できる。これらの領域がどのように確立する かは重要な問題である。

シロイヌナズナのCUP-SHAPED COTYLEDON 1 （CUC1）およびCUC2遺伝子は機能的に重複 した遺伝子で、どちらか一方の機能欠失だけではほとんど表現型を示さず、二重変異体で初めて表 現型を示す（Aida et al. 1997; Aida et al. 1999）。cuc1 cuc2二重変異体の芽生えは茎頂分裂組織を 完全に欠失するとともに、2 枚の子葉が融合してカップ型になる（図 $2 \mathrm{~A}$ ）。この変異体の胚発生 では、子葉と子葉の境界部（boundary of cotyledon margins; bcm）が異所的に盛り上がっており

（図 $2 \mathrm{D} 、$ 矢じり）、これが原因で子葉の融合が起こることがわかった。これらのことから、CUC1 とCUC2は中央部において茎頂分裂組織の確立に働くとともに、 bcmの盛り上がりを抑制する過程 にも重要な役割を果たしていることが示唆される。

cuc1 cuc2と良く似た表現型は、SHOOT MERISTEMLESS（STM）遺伝子の突然変異によって も引き起こされる。stm突然変異体は茎頂分裂組織を欠失し、子葉もごくわずかではあるが融合す 

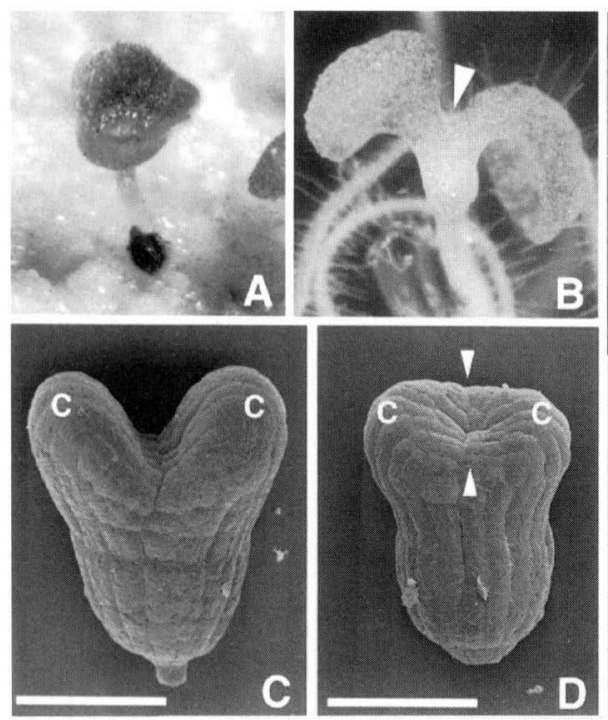
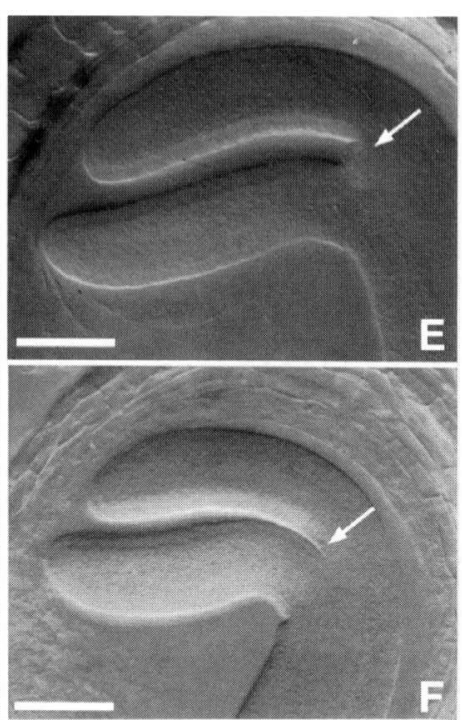

図 $2 \quad c u c 1 \quad c u c 2$ 二重変異体 とstm変異体の表現型.

A : cuc1 cuc2の芽生え.

B : stmの芽生え。葉が基 部でわずかに融合する（矢 じり).

CとD：野生型（C）および cuc1 cuc2 (D) の心臟型胚 の電子顕微鏡像。cは子葉原 基, 矢じりは子葉原基の境 界部（bcm）を示す。スケー ルバーは $40 \mu \mathrm{m}$.

$\mathrm{E} と \mathrm{~F}$ ：野生型（E）および $s t m$ （F）の子葉屈曲期の胚 のノマルスキー像. 矢印は 子葉の基部を示す。スケー ルバーは $50 \mu \mathrm{m}$.

る(図 2 B; Barton and Poethig 1993; Clark et al. 1996; Endrizzi et al. 1996; Long and Barton 1998）。このことから $S T M$ 遺伝子も $C U C 1$ や $C U C 2$ と同様、茎頂分裂組織の形成とbcmの盛り上が りを抑制する過程に必要なことが示唆される。CUC2とSTMはクローニングされており、mRNAの 発現パターンが詳細に調べられた（Long et al. 1996; Long and Barton 1998; Aida et al. 1999）。 その結果、両遺伝子の発現は茎頂分裂組織の発生にともなってダイナミックに変化することがわ かった（図 $3 \mathrm{~A} ） 。$

CUC2は球状胚初期に頂端側の数細胞で発現をはじめ、球状胚後期になると予定子葉領域の間の 帯状にのびた領域で発現が拡がる。その後子葉屈曲期になると、CUC2の発現は中央の茎頂分裂組 織で抑制されて、 b c mおよび茎頂分裂組織と子葉の境界部に限定される。一方、STMの発現は CUC2よりやや遅れて起こるが、CUC2 と同様に子葉原基の間で帯状に発現する。しかし茎頂分裂組 織が確立してくるにつれ、その発現は中央の茎頂分裂組織のみに限定されてくる。これらの発現パ ターンとそれぞれの変異体の胚発生後の表現型の特徵（Aida et al. 1997; Clark et al. 1996; Endrizzi et al. 1996）から、CUC2は器官どうしの境界部や器官と茎頂分裂組織の境界部の分化に 重要な役割を持つことが示唆される。一方、STMは茎頂分裂組織の形成と維持に直接機能すること が示唆される。

$S T M$ 発現の開始はCUC1とCUC2に依存しており、cuc1 cuc2二重変異体ではSTMの発現が全く 起こらない。このことからCUC1とCUC2はSTMの発現の開始を正に制御することで茎頂分裂組織 の形成に関与することが示唆される。一方、stmの変異体ではCUC2の初期の発現は正常だが、後期 の発現パターンが乱れる。このことからSTM はCUC2 の後期の発現の空間的なパターンを制御する

図 3 シロイヌナズナの肧頂端部の 領域化.

A : CUC2およびSTMのmRNAの発 現パターンを肧上方から見た模式 図. c は子葉, sは茎頂分裂組織を示 す.

B：初期胚に内在すると考えられる 2 種の位置情報. i : bilateralパター ン. ii : radialパターン.
(A)

CUC2

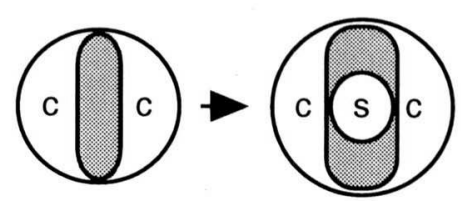

(B) (i)

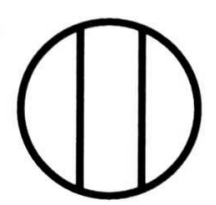

$S T M$ (ii)

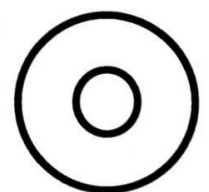


ことで、子葉境界部の盛り上がりを抑制する過程に寄与すると考えられる (Aida et al. 1999)。

以上のように、茎頂分裂組織およびbcmが正常に分化するためにはCUC1、CUC2、STMの相互 作用が必要である。CUC2やSTMに見られる発現パターンの変化は、胚に内在する位置情報のパ夕 ーンを暗示しており、非常に興味深い（Long and Barton 1998; Aida et al. 1999）。CUC2やSTM の初期の発現パターンは、予定子葉領域とその間の境界部分を区別するようなbilateralな位置情報 が存在し、それに基づいてCUC2やSTMの発現が起こることを示唆している（図 $3 \mathrm{~B}$ i）。一方、後 期における両遺伝子の発現パターンには、胚の中心部と周辺部を分けるような、radialな位置情報 が関与しているのかもしれない（図 $3 \mathrm{~B}$ ii）。後者のタイプの位置情報を反映していると考えられる 別の遺伝子として、AINTEGUMENTA (ANT) がある。この遺伝子は球状胚初期に発現を開始 し、球状胚後期になると周辺部でリング状の発現をすることから、 radialな位置情報はすでに球状 胚後期に形成されている可能性がある（Long and Barton 1998）。この様な 2 つのタプの位置情 報は、初期胚におけるパターン形成過程と密接に関わっていると予想できる。

\section{CUC2によるSTMの発現開始の制御}

$S T M$ は茎頂分裂組織の形成および維持過程に中心的な役割を果たしていると考えられており、こ の遺伝子の発現開始は茎頂分裂組織形成における重要なステップの一つであると考えられる。 CUC2はどのようにしてSTMの発現を正に制御するのであろうか。CUC2はペチュニアのNO APICAL MERISTEM (NAM) に相同な遺伝子をコードする (Souer et al. 1996; Aida et al. 1997）。CUC2およびNAM遺伝子の産物はN末にNACドメインという高度に保存された配列を持 つ。NACドメインを持つタンパク質はシロイヌナズナ、ペチュニア、イネなど多くの植物で報告さ れており、一つの植物種においても多数の遺伝子が存在する (Souer et al. 1996; Aida et al. 1997; John et al. 1997; Sablowski and Meyerowitz 1998; Souer et al. 1998; Ruiz-Medrano et al. 1999; Xie et al. 1999）。CUC2も含め、いくつかのNAC遺伝子に関しては、醅母を用いた実験系において 転写の活性化能を持つことがわかっている（Souer et al. 1996; Duval and Thomas, 私信; Taoka, 未 発表）。このことは、NAC遺伝子が転写制御に関係することを示唆しており、CUC2がSTMの転写 を直接活性化する可能性を示している。もちろん、他の未知の因子を介してSTMの発現に間接的に 関わっている可能性もある。

ペチュニアのnam変異体はcuc1 cuc2二重変異体とよく似た表現型を示し、茎頂分裂組織を欠失す るとともに、子葉どうしが片側で部分的に融合する（Souer et al. 1996）。このことからNAMも茎 頂分裂組織の形成に重要であることが示唆される。興味深いことに、NAMの発現は茎頂分裂組織の 予定領域そのものではなく、そのすぐ周りで起こる。このことは、NAM遺伝子が茎頂分裂組織の形 成に関して細胞非自立的に機能することを示唆している。これに対してCUC2の場合、少なくとも 初期においては茎頂分裂組織の予定域そのもので発現がみられる。CUC2とNAMの発現パターンの 違いが両者の機能の仕方の違いを反映しているのか、それともCUC2もNAM同様に細胞非自立的に 機能しうることを意味しているのかは不明である。

nam変異体の芽生えは、しばしば不定芽を生ずる（Souer et al. 1996）。またcuc1 cuc2変異体も カルス化を経ることで不定芽を誘導できる（Aida et al. 1997）。どちらの場合も、一度形成された 不定芽の分裂組織はほぼ正常に維持されることから、CUC1、CUC2、NAMは茎頂分裂組織の維持 過程には必要でない可能性がある。あるいはこれらの遺伝子の欠失を補うような、機能的に重複し 
た別の遺伝子が存在するのかもしれない。

シロイヌナズナのAtNAC1遺伝子はCUC2に非常に相同性の高い遺伝子であり、胚発生における 発現パターンも良く似ている。この遺伝子を過剩発現させた植物体では、子葉や本葉の表面から異 所的に茎頂分裂組織を形成することから、この遺伝子も茎頂分裂組織の形成に重要な役割を果たす ことが示唆される（Takada, Hibara, Ishida and Tasaka，投稿準備中）。AtNAC1の発現開始は CUC2とほぼ同時期であり、STMよりやや早く始まることから、AtNAC1もSTMの上流で機能して いる可能性がある。

\section{STMによる茎頂分裂組織形成の制御}

野生型シロイヌナズナの胚発生では、まず魚雷胚期までに頂端部に茎頂分裂組織の元となる 3 層 の細胞層が形成される。これらは子葉屈曲期になると外衣・内体に特有な分裂パターンをとり始 め、ドーム状に拡がった構造になる（図 $2 \mathrm{E}$ ）。stm変異体ではこの外衣・内体に特有な細胞分裂が まったく起こらず、子葉どうしが直接基部で接する（図 $2 \mathrm{~F}$; Barton and Poethig 1993）。このこ とから、STMは茎頂分裂組織の細胞が規則的に増殖する過程に必要であることが示唆される。一方 $S T M$ 活性が部分的に残っている弱い変異アリルでは、子葉と子葉の間に茎頂分裂組織の特徵を 持った細胞が少しだけ形成される。しかし、これらの細胞は全て、発芽後すぐに葉に分化してしま う（Clark et al. 1996; Endrizzi et al. 1996）。このことから、STMは茎頂分裂組織の細胞が器官原 基に分化するのを抑制する働きを持つことが示唆される。

STMはトウモロコシのKNOTTED1（KN1）型のホメオドメインタンパクと相同なタンパク質を コードする (Long et al. 1996)。ホメオドメインはDNA結合能を持つ領域で、これを含むタンパ ク質は転写因子として機能する事が多くの生物においてわかっている（Gehring et al. 1994）。 $S T M$ 含むいくつかの KN1型の遺伝子は、胚発生の初期に茎頂分裂組織の予定領域で発現が始まる

（Smith et al. 1995; Long et al. 1996; Sato et al. 1996）。茎頂分裂組織が確立した後は、植物体の 一生を通じて茎頂分裂組織の未分化な領域に局在し、葉原基が出現する予定領域では発現が抑制さ れる（Smith et al. 1995; Long et al. 1996; Sentoku et al. 1999）。また、KN1やそのホモログを夕 バコやシロイヌナズナで過剩発現すると、葉の表面から茎頂分裂組織が異所的に形成される （Sinha et al. 1993; Lincoln et al. 1994; Sato et al. 1996）。これらの結果から、KN1型の遺伝子 は茎頂分裂組織の形成および維持に中心的な役割を果たすと考えられている。

STMが転写因子として働くとすると、STMによって転写を調節されるターゲット遺伝子が存在す ることが予想される。これまでにSTMのターゲットであることが証明された遺伝子は皆無である が、一つの候補としてUNUSUAL FLORAL ORGANS（UFO）があげられる。UFO mRNAの発現 はSTMの発現開始のすぐ後にSTMの発現領域内で始まり、その後一生を通じて茎頂分裂組織で発現 し続ける（Long and Barton 1998）。stm変異体の胚ではUFO mRNAが全く検出されないことか ら、UFOの発現はSTMに依存していることがわかる。UFOはもともと花のパターン形成に異常を 引き起こす突然変異の原因遺伝子として同定された。しかしufo変異体の胚は特に表現型が見られな いので、胚発生におけるUFO遺伝子の役割は不明である。

\section{7. 茎頂分裂組織の維持に関わる遺伝子群の胚発生における発現}

茎頂分裂組織はいったん形成されると、頂端部に幹細胞を維持しながら新しい器官を繰り返し造 り続ける。植物の発生にとって根元的ともいえるこのプロセスが維持されるためには、茎頂分裂組 
織における細胞の増殖と分化がバランスよく保たれなければならない。この過程を制御する遺伝子 としてシロイヌナズナのSTM、WUSCHEL (WUS)、CLAVATA1（CLV1）、CLV3などが知ら れている（総説：Clark 1997; Lenhard and Laux 1999）。すでにSTMの胚発生における発現につ いては述べたが、そのほかのいずれの遺伝子も胚発生のかなり初期から発現を始める（図 4 ）。こ のことは、茎頂分裂組織における細胞増殖と分化の調節プログラムが、茎頂分裂組織の構造が明ら かになるより前にすでに始まっていることを示唆している。

wuschel (wus) 変異体の肧では正常な茎頂分裂組織が形成されず、かわりに平らな形をした構造 が形成される。発芽後、この構造は数枚の本葉を形成しては停止するという過程を繰り返す。この 表現型から、WUS遺伝子は茎頂分裂組織の機能的統合に不可欠な遺伝子であり、茎頂分裂組織中の 幹細胞の性質を規定する働きを持つという興味深いモデルが提唱されている（Laux et al. 1996; Mayer et al. 1998）。WUS遺伝子はKN1型とは異なる新しいタイプのホメオドメインタンパクをコ 一ドしており、茎頂分裂組織内部の非常に狭い領域で発現する。

胚発生におけるWUSの発現は非常に早く始まり、茎頂分裂組織の構造が明確になるよりはるか以 前の 16 細胞期に最初の発現がみられた。この時期WUSは、頂端部内側の 4 つの細胞で検出され る。その後これらの細胞に由来する娘細胞の一部でのみ発現を継続し、最終的に茎頂分裂組織が確 立した後は幹細胞が存在する領域のすぐ下側の数細胞で発現を続けるようになる。wus変異体の異 常は茎頂分裂組織のみに限られており、表現型が現れる時期も胚発生のかなり後期であることを考 えると、WUS遺伝子の発現がこれだけ早い時期に開始されるのは驚きである。正常な茥頂分裂組織 が形成されるためには、あらかじめかなり早い時期からWUSによって幹細胞が規定され、維持され る必要があるのかもしれない。

$C L V 1$ おびCLV3遺伝子は茥頂分裂組織の細胞が未分化な状態から分化した状態へ移るのを促進 する遺伝子で、未分化状態の維持に㗢くSTMと互いに拮抗する関係にある (Clark et al. 1996)。こ れらの遺伝子に変異が起こると未分化細胞が徐々に蓄積するので茎頂分裂組織が巨大化する (Clark et al. 1993; Clark et al. 1995; Laufs et al. 1998）。CLV1遺伝子は受容体型キナーゼをコードし、 CLV3は新規の低分子量分泌性タンパクをコードしていた（Clark et al. 1997; Fletcher et al. 1999）。遺伝学的解析から両遺伝子は同一経路で働くことが示唆されており、CLV3はCLV1のリガ ンドとして機能することが予想されている。CLV3は外衣の頂端部で強く発現がみられ、一方 $C L V 1$ は内体において主に発現していた。これらのことから、CLV1とCLV3が茎頂分裂組織での細胞層間 のコミュニケーションをになうシグナル伝達因子であることが示唆される。どちらの遺伝子も心臓 胚期から胚の頂端部で発現が始まる（Long and Barton 1998; Fletcher et al. 1999）。

このようにWUS、STM、CLV遺伝子の胚発生における発現開始の夕イミングは、茎頂分裂組織 の構造が明確になるよりかなり早い（図 4)。また各遺伝子の発現は、胚発生の特定の時期に一斉 に始まるのではなく、少しずつずれて始まっている。つまり、茎頂分裂組織の確立は胚発生のかな り初期から始まり、いくつかのステップを経て徐々に進行して行く過程である、ととらえることが 出来る。それでは、例えばSTMの発現開始は、その前に発現を始めるWUSに依存するのであろう か。あるいは $C L V$ の発現開始はSTMやWUSに依存するのだろうか。突然变異体を用いた発現解析 から、STMの発現開始はWUS遺伝子がなくても起こり、WUSの発現開始もSTMに依存しないこと がわかった（Mayer et al. 1998）。またCLV1の発現開始もSTMに依存していなかった（Long and Barton 1998）。これらのことから、調べた限りにおいて、茎頂分裂組織の維持過程に関わる遺伝 子の発現開始は互いに独立に制御されていることが示唆される。これらの遺伝子の発現開始を制御 


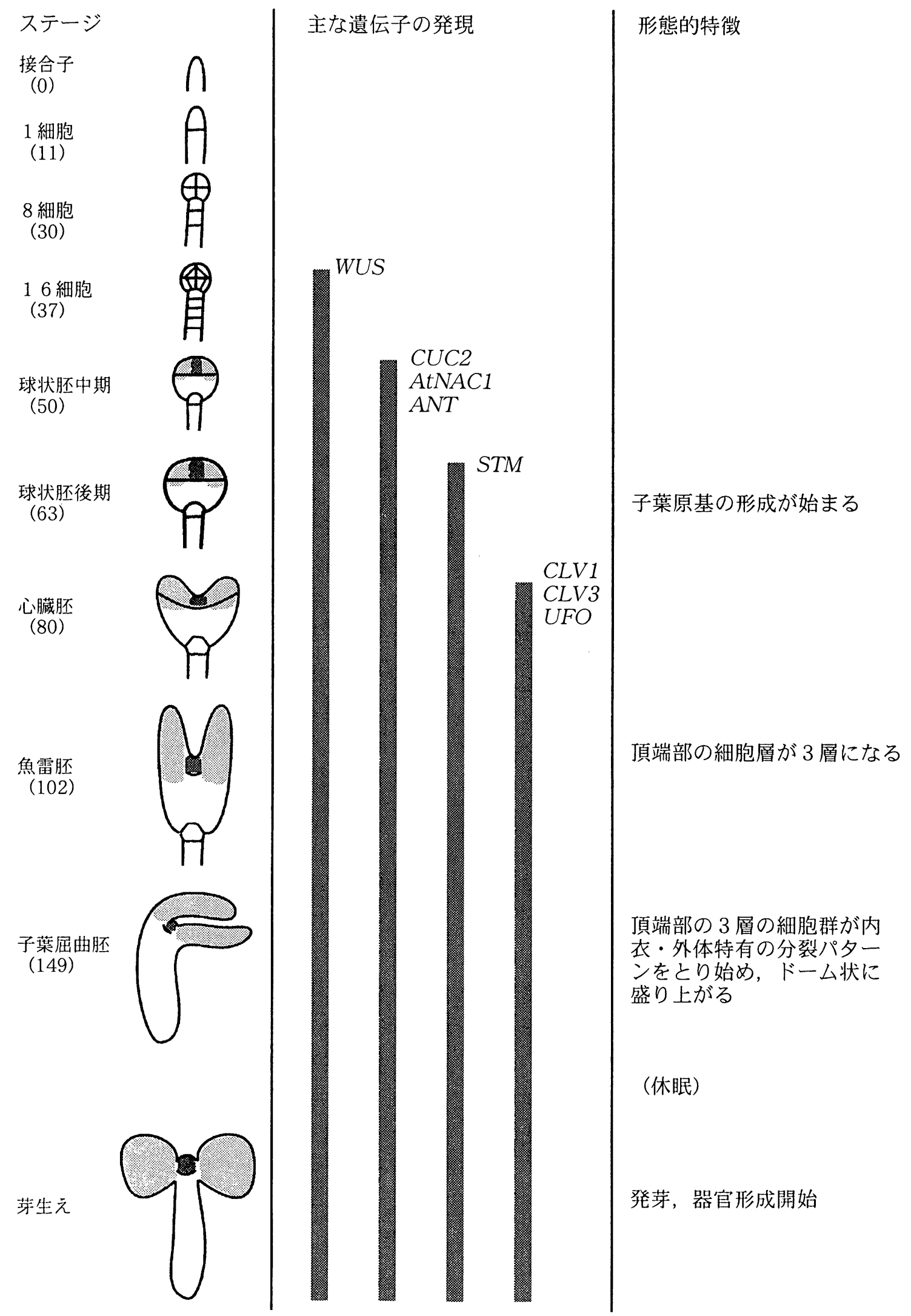

図 4 シロイヌナズナにおける, 茎頂分裂組織形成・維持に関わる遺伝子群の発現の模式図. 各 ステージの下のカッコ内の数字は受精後のおよその時間経過を表す (Jürgens and Mayer 1994 より算出）。単位は時間。 
する共通の経路が存在するかどうかは不明である。

\section{8. 茎頂分裂組織と葉の背腹性との関係}

茎頂分裂組織の形成は自立的なもので、周りの組織とは独立に起こるのであろうか。それとも周 囲の組織と何らかの相互作用があるのだろうか。胚発生における一次分裂組織は 2 つの子葉の間に 形成される。一方、後胚発生的に形成される腋生分裂組織は葉腋に形成される。いくつかの突然変 異体や形質転換植物の解析により、茎頂分裂組織の形成や維持には、葉や子葉の背腹性と密接な関 係があることがわかってきた。

シロイヌナズナの突然変異体phabulosa-1d（phb-1d） は葉の背腹性が異常になり、両面とも向軸 側の組織の性質を持つようになる（McConnell and Barton 1998）。このような葉では、本来の腋 に相当する側だけでなく、その反対側からも異所的に茎頂分裂組織が形成される。このことから、 茎頂分裂組織の形成は葉の向軸側の性質に依存することが示唆される。同様のことは、KN1型の遺 伝子や CUC2相同遺伝子である AtNAC1の過剩発現による茎頂分裂組織の異所的形成が、葉や子葉 の向軸側に特異的に起こることからも示唆される。一方、シロイヌナズナのFILAMENTOUS $F L O W E R$ や $Y B B Y 3$ 3葉の背軸側の運命の決定に関わる転写因子をコードすると考えられている が、これらの遺伝子を過剩発現させた植物体では両面とも背軸側の性質を持つ子葉や葉が形成され る（Sawa et al. 1999; Siegfried et al. 1999）。そしてこの様な植物体では、一次分裂組織がいくつ かの側方器官を形成した後に停止してしまう。このことから葉の背軸側は、向軸側とは逆に茎頂分 裂組織の発生に抑制的に働くことが示唆される。

胚で形成される一次分裂組織は子葉の基部の向軸側に位置する。子葉の背腹性は一次分裂組織の 発生に影響を与えるのだろうか。phb-1d変異体では子葉の両面が向軸側の性質を示し、一次分裂組 織が巨大化する（McConnell and Barton 1998）。また、この変異はstm変異体の表現型（茎頂分 裂組織が形成できないという表現型）を部分的に抑制する。これらの結果は、子葉の向軸側の性質 が一次分裂組織の形成を促進する可能性を示唆している。

以上に挙げた結果から、子葉や葉の向軸側は茎頂分裂組織の形成や維持を促進する能力を持つこ とが示唆される。このような性質の分子的実体は明らかではない。シロイヌナズナの PINHEADIZWILLE (PNH) 遺伝子は子葉や葉の向軸側で発現がみられ、この遺伝子に変異が起こ ると一次分裂組織や腋生分裂組織の形成能力が低下する (McConnell and Barton 1995; Lynn et al. 1999）。このことから、PNH遺伝子は向軸側における茎頂分裂組織形成の反応能 (competence) に関与しているのではないかという仮説が提唱されている。PNH遺伝子がコードするタンパク質は ウサギから単離された翻訳の開始因子 $\mathrm{eIF} 2 \mathrm{C}$ に相同であることから、他の遺伝子の翻訳を制御する 機能を持つ可能性がある（Zou et al. 1998; Lynn et al. 1999）。

9.おわりに

本稿で紹介したように、近年の分子遺伝学的アプローチから茎頂分裂組織の形成に関わる遺伝子 が多く同定・クローニングされ、この過程を制御する遺伝的メカニズムについての理解が進んだ。 一方で、茎頂分裂組織の形成にはここで挙げたよりも多くの調節遺伝子が存在することが予想され る。こうした未知の遺伝子を同定していくためには、既知の変異体のサプレッサーやエンハンサー 変異の単離、転写因子のターゲット遺伝子の探索、two-hybrid法による相互作用する因子の単離な ぞ、多彩なアプローチが行われていくと思われる。また、これまで解析された主な変異体は発芽後 
の芽生えの表現型を指標にスクリーニングされたものであるが、この方法では胚発生の段階で死ん でしまう胚致死変異体を得ることが出来ない。茎頂分裂組織の形成プログラムが胚発生のかなり初 期から始まっていることを考えると、今後は胚致死変異体の中から目的の変異体を探すことも重要 になってくると考えられる。WUS、CUC2、STMなどの遺伝子の発現は、そのようなスクリーニン グの際に有効なマーカーとして使えるであろう。

\section{謝辞}

本稿を執筆するにあたって、貴重な助言をいただいた田坂昌生教授および田坂研究室のメンバー に感謝いたします。

文献

Aida, M., Ishida, T., Fukaki, H., Fujisawa, H., Tasaka, M. (1997) Genes involved in organ separation in Arabidopsis: an analysis of the cup-shaped cotyledon mutant. Plant Cell 9: 841-857.

Aida, M., Ishida, T., Tasaka, M. (1999) Shoot apical meristem and cotyledon formation during Arabidopsis embryogenesis: interaction among the CUP-SHAPED COTYLEDON and SHOOT MERISTEMLESS genes. Development 126: 1563-1570.

Barton, M.K., Poethig, R.S. (1993) Formation of the shoot apical meristem in Arabidopsis thaliana: an analysis of development in the wild type and in the shoot meristemless mutant. Development 119: 823-831.

Clark, S.E. (1997) Organ formation at the vegetative shoot meristem. Plant Cell 9: 1067-1076.

Clark, S.E., Jacobsen, S.E., Levin, J.Z., Meyerowitz, E.M. (1996) The CLAVATA and SHOOT MERISTEMLESS loci competitively regulate meristem activity in Arabidopsis. Development 122: 1567-1575.

Clark, S.E., Running, M.P., Meyerowitz, E.M. (1993) CLAVATA1, a regulator of meristem and flower development in Arabidopsis. Development 119: 397-418.

Clark, S.E., Running, M.P., Meyerowitz, E.M. (1995) CLAVATA3 is a specific regulator of shoot and floral meristem development affecting the same processes as CLAVATA1. Development 121: 2057-2067.

Clark, S.E., Williams, R.W., Meyerowitz, E.M. (1997) The CLAVATA1 gene encodes a putative receptor kinase that controls shoot and floral meristem size in Arabidopsis. Cell 89: 575585.

Endrizzi, K., Moussian, B., Haecker, A., Levin, J.Z., Laux, T. (1996) The SHOOT MERISTEMLESS gene is required for maintenance of undifferentiated cells in Arabidopsis shoot and floral meristems and acts at a different regulatory level than the meristem genes WUSCHEL and ZWILLE. Plant J. 10: 967-979.

Evans, M.M.S., Barton, M.K. (1997) Genetics of angiosperm shoot apical meristem development. Annu. Rev. Plant Physiol. Plant Mol. Biol. 48: 673-701.

Fletcher, J.C., Brand, U., Running, M.P., Simon, R., Meyerowitz, E.M. (1999) Signaling of cell fate decisions by CLAVATA3 in Arabidopsis shoot meristems. Science 283: 1911-1914.

Gehring, W.J., Affolter, M., Burglin, T. (1994) Homeodomain proteins. Annu. Rev. Biochem. 63: 487-526.

John, I., Hackett, R., Cooper, W., Drake, R., Farrell, A., Grierson, D. (1997) Cloning and characterization of tomato leaf senescence-related cDNAs. Plant Mol. Biol. 33: 641-651.

Jürgens, G., Mayer, U. (1994). Aradbidopsis. In Embryos: Colour Atlas of Development, J. Bard, ed. (London: Wolfe), pp. 7-21.

Kaplan, D.R., Cooke, T.J. (1997) Fundamental concepts in the embryogenesis of dicotyledons: a morphological interpretation of embryo mutants. Plant Cell 9: 1903-1919.

Laufs, P., Grandjean, O., Jonak, C., Kieu, K., Traas, J. (1998) Cellular parameters of the shoot apical meristem in Arabidopsis. Plant Cell 10: 1375-1390.

Laux, T., Mayer, K.F.X., Berger, J., Jürgens, G. (1996) The WUSCHEL gene is required for 
shoot and floral meristem integrity in Arabidopsis. Development 122: 87-96.

Lenhard, M., Laux, T. (1999) Shoot meristem formation and maintenance. Curr. Opin. Plant Biol. 2: 44-50.

Lincoln, C., Long, J., Yamaguchi, J., Serikawa, K., Hake, S. (1994) A knotted1-like homeobox gene in Arabidopsis is expressed in the vegetative meristem and dramatically alters leaf morphology when overexpressed in transgenic plants. Plant Cell 6: 1859-1876.

Long, J.A., Barton, M.K. (1998) The development of apical embryonic pattern in Arabidopsis. Development 125: 3027-3035.

Long, J.A., Moan, E.I., Medford, J.I., Barton, M.K. (1996) A member of the KNOTTED class of homeodomain proteins encoded by the STM gene of Arabidopsis. Nature 379: 66-69.

Long, J.A., Woody, S., Barton, M.K. (1999) A mutation at the TOPLESS locus causes shoot to root transformations during embryogenesis. 10th International Conference on Arabidopsis Research abstracts: http://arabidopsis.en-bio.com.au/cgi-bin/search/search.cgi

Lyndon, R.F. (1998). The shoot apical meristem (Cambridge: Cambridge University Press).

Lynn, K., Fernandez, A., Aida, M., Sedbrook, J., Tasaka, M., Masson, P., Barton, M.K. (1999) The PINHEADIZWILLE gene acts pleiotropically in Arabidopsis development and has overlapping functions with the ARGONAUTE1 gene. Development 126: 469-481.

Mayer, K.F.X., Schoof, H., Haecker, A., Lenhard, M., Jürgens, G., Laux, T. (1998) Role of WUSCHEL in regulating stem cell fate in the Arabidopsis shoot meristem. Cell 95: 805815.

McConnell, J.R., Barton, M.K. (1995) Effect of mutations in the PINHEAD gene of Arabidopsis on the formation of shoot apical meristems. Dev. Genet. 16: 358-366.

McConnell, J.R., Barton, M.K. (1998) Leaf polarity and meristem formation in Arabidopsis. Development 125: 2935-2942.

Ruiz-Medrano, R., Xoconostle-Cazares, B., Lucas, W.J. (1999) Phloem long-distance transport of CmNACP mRNA: implications for supracellular regulation in plants. Development 126 : 4405-4419.

Sablowski, R.W.M., Meyerowitz, E.M. (1998) A homolog of NO APICAL MERISTEM is an immediate target of the floral homeotic genes APETALA3/PISTILLATA. Cell 92: 93-103.

Sato, Y., Hong, S.K., Tagiri, A., Kitano, H., Yamamoto, N., Nagato, Y., Matsuoka, M. (1996) A rice homeobox gene, $O S H 1$, is expressed before organ differentiation in a specific region during early embryogenesis. Proc. Natl. Acad. Sci. USA 93: 8117-8122.

Sato, Y., Tamaoki, M., Murakami, T., Yamamoto, N., Kano-Murakami, Y., Matsuoka, M. (1996) Abnormal cell divisions in leaf primordia caused by the expression of the rice homeobox gene $\mathrm{OSH} 1$ lead to altered morphology of leaves in transgenic tobacco. Mol. Gen. Genet. 251: 13-22.

Sawa, S., Watanabe, K., Goto, K., Kanaya, E., Morita, E.H., Okada, K. (1999) FILAMENTOUS FLOWER, a meristem and organ identity gene of Arabidopsis, encodes a protein with a zinc finger and HMG-related domains. Genes Dev. 13: 1079-1088.

Sentoku, N., Sato, Y., Kurata, N., Ito, Y., Kitano, H., Matsuoka, M. (1999) Regional expression of the rice $K N$ 1-type homeobox gene family during embryo, shoot, and flower development. Plant Cell 11: 1651-1664.

Siegfried, K.R., Eshed, Y., Baum, S.F., Otsuga, D., Drews, G.N., Bowman, J.L. (1999) Members of the $Y A B B Y$ gene family specify abaxial cell fate in Arabidopsis. Development 126: 4117-4128.

Sinha, N.R., Williams, R.E., Hake, S. (1993) Overexpression of the maize homeo box gene, KNOTTED-1, causes a switch from determinate to indeterminate cell fates. Genes Dev. 7: 787-795.

Smith, L.G., Jackson, D., Hake, S. (1995) Expression of knotted-1 marks shoot meristem formation during maize embryogenesis. Dev. Genet. 16: 344-348.

Souer, E., van Houwelingen, A., Bliek, M., Kloos, D., Mol, J., Koes, R. (1998) Co-suppression of nam and homologous genes leads to a reduction in axillary meristem formation and increased leaf and stem size in petunia: a possible role for NAC domain genes in plant development. Flowering Newslett. 26: 36-46.

Souer, E., van Houwelingen, A., Kloos, D., Mol, J., Koes, R. (1996) The no apical meristem gene of Petunia is required for pattern formation in embryos and flowers and is expressed at 
meristem and primordia boundaries. Cell 85: 159-170.

Steeves, T.A., Sussex, I.M. (1989). Patterns in Plant Development, 2nd. Edition (Cambridge: Cambridge University Press).

Sussex, I.M. (1989) Developmental programming of the shoot meristem. Cell 56: 225-229.

Wolpert, L., Beddington, R., Brockes, J., Jessell, T., Lawrence, P., Meyerowitz, E. (1998). Principles of development (London: Current Biology Publications).

Xie, Q., Sanz-Burgos, A.P., Guo, H., Garcia, J.A., Gutierrez, C. (1999) GRAB proteins, novel members of the NAC domain family, isolated by their interaction with a geminivirus protein. Plant Mol. Biol. 39: 647-656.

Zou, C., Zhang, Z., Wu, S., Osterman, J.C. (1998) Molecular cloning and characterization of a rabbit eIF2C protein. Gene 211: 187-194. 